結論

1. 瀨の化学療法郕として余等は一新化合物PAShdrazide ( $p$-aminosalicylic acid hydrazide, 2-oxy-4-aminobenzoic hydrazide) を合成した。

2.PAShudrazideを鼠瀨に注射しその発症に及ぼす影 響学観祭したが対照に比しその発症程度は軽度でむり， PAShdrazide は鼠顀の発症を可成り抑制する。

3. PAShudrazide の鼠瀨に対する影響をPAS, 並びに INAH それと比較したが鼠瀨の発症抑制効年は殆ど同一 程度でむつた。

\section{文献}

1. 加来天民，加瀬佳年，作間忠行：2-Phenylcincho- nic Acid Hydrazide 及び p-Aminosalicylic Acid Hydrazide の研究, 萫学雑誌, 第 73 巻, 第 6 号, (昭和28年)

2. Th. Curtius: J. Prakt. Chem., (2) 50, 278, (1894)

3. G. Struve : Ilbid., (2) 50, 295, (1894)

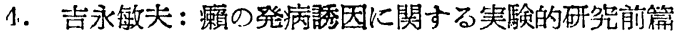
レプラ，第 21 巻，第 2 号（昭和 27 年）

5. 吉永敏夫：㴡の発病誘因関する実験的研究後篇 レプラ, 同上

6. 佐谷有吉, 西村真二, 河野通之, 増田太郎, 園田 龍三：イソニコチン酸ヒドラジット誘導体の鼠瀨発 症阻止実験, 日本颗学会西部地方会第 2 回総会演題 抄塗，（昭和28年）

\title{
THE INHIBITORY AND THE TRAPEUTIC EFFECTS OF INAH ON RAT LEPROSY
}

\author{
Studies on Rat Leprosy (25)
}

\section{YASURO TAKAYAMA}

Dept. of Bacteriology, Hiroshima Medical School (Director: Prof. K. Urabe)

Evaluating the influence of INAH on rat leprosy, based upon the degree of enlargment of leproma and dissmlnation of leprosy bacilli into tissues, it seemes to be much or less active for the inhibition of the development of and therapeutic effect on rat leprosy in hamster.

\section{NAH 投与の鼠癩の発症阻止: 並びに治療効果について 一鼠瀨の研究 (25) -} 厇島大学医学部細菌学教窒（主任 占部教授） 高山保郎

(昭和 28 年 11 月 28 日受稿)

（この研究は 1 部文部省科学研究費によつた。占部）

\section{楮言}

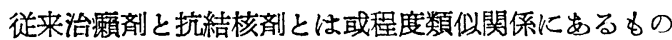
が少くないといわれているが，近年新たに結核治療薬と して注目を浴びた INAH も人瀨に対して治効のあると
とが既に多数報告されて居り，(1〜5)，又鼠瀨に対しても 可成りの治効があり発症防止能はないが，肉芽腫の増大 進筀を阻止し得るとの報告も見られる。( ${ }^{6}$ - 8)

そこで私は一連の化学療法剤による鼠癩治療実験の一 端として，今回は INAH 投与による鼠癩発症阻止並び 
に治療効果の検討を行つたので以下報告する。

\section{実験材料並びに方法}

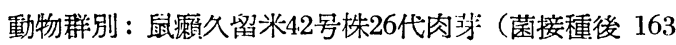
日）より約 50 倍生塩水加乳剂を作り，之を 1.000 回転 10

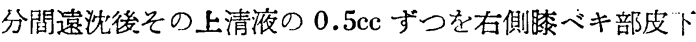
に接種したハムスター（体重60１10g）を 1 群 6 匹宛と して, 第 1 群は治療実験群, 第 2 群は発症阻止実験群, 第 3 群は無処置対照群とした。

供試薬品：INAH は Hycocid(武田薬工) を使用した。

薬垖投与量並びに方法：図 1 に示すように第 1 群には 鼠瀨菌接種 3 週後より, 第 2 群には接種感染直後よりそ れぞれ INAH に適当量の乳糖を加えてガラス製小匙で 毎日経口投与したが,そのさい,両群とも始めの 2 週間は INAH $0.2 \mathrm{mg}$ ずつを，次の 2 週間は $0.3 \mathrm{mg}$ ずつを投与 し，その後は $0.4 \mathrm{mg}$ ずつを第 1 群には 9 週間にわたり， 又第 2 群には 12 週間投与を続けた後直ちに（鼠浼菌接種 感染16淍後)いずれも無処置対照群と共に屠殺剖検しだ。 因に投与総量は第 1 群 $32.2 \mathrm{ng}$ ，第 2 群 $40.6 \mathrm{mg}$ である。

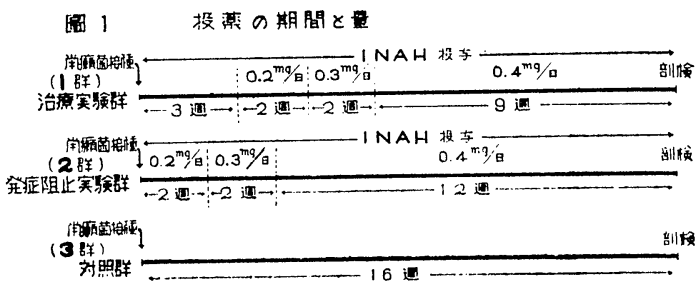

成績観祭法：体表变化，鼠裙性肉芽の状態，各淋巴腺 並びに内臟の肉眼的所見を観祭し且つZiehl-Neelsen 染 色標本による鼠瀨菌の分布度の追及及びパラフィン切片 橴本について病理組織学的検索をも扎てなつた。

\section{実験成繀}

1）投楽継続中の所見：INAH による副作用について は船始注意していたが，各試獣は一般に元気で，四 2 に 示す上5に体重は対照（第 3 ）群に於て感染後 2 週頃迄 減少したのに反して INAH 投与の 1 群 2 群ではむしろ 増加の傾向を示した。但し 8〜10週以後からは全群僅か ながら体重減少の一途を辿つたが，外見上には誌むべき 異状はみられなかつた。

右側膝べキ部には鼠澡菌感染後结ぼ 3 週頃より 3 群間 にいう程の差のない程度に瀨性肉芽を触れ始めたが，剖 椧してみると肉辅の程度は 3 群> 1 群> 2 群の順を示し た。

な抢， 3 群とる等しく終始体表面に潰源, 瘦孔はみら れなかつた。

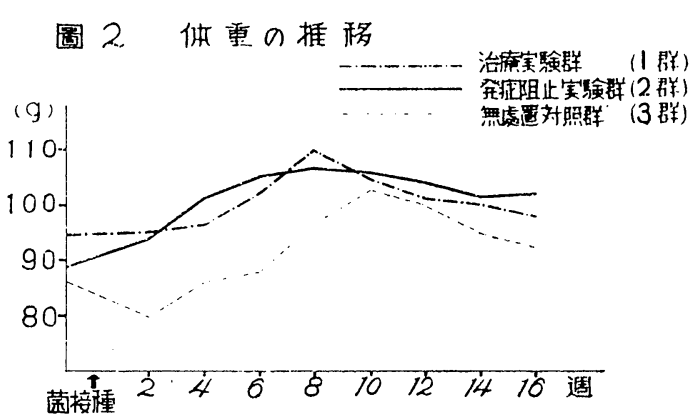

2）肉眼的剖検所見：一般に菌接種部皮下゙にはび慢性 脆弱菲燃膜状の肉芽組織から腫瘤状瀨腫に至る迄の種々 の程度の変化が認められたが，ただ第 2 群 No.6 の試獣 のみには極めてすう疎な肉芽样組織がわずかに存在して いたにすぎなかつた。

右側膝べキ淋巴腺は $2 \cdot 3$ の例外を除いて左側のそれと 同程度か或はより腫大していたものが多く, 文左右膝へ キ並びに腋简各淋巴腺には淡黑褐色の斑点が可成りの頻 度に於て認められたが乾酪様変性に楩つたものはなかつ た。

以上の所見を総括してヒストグラムに示すと闵 3 の如 くでめる。

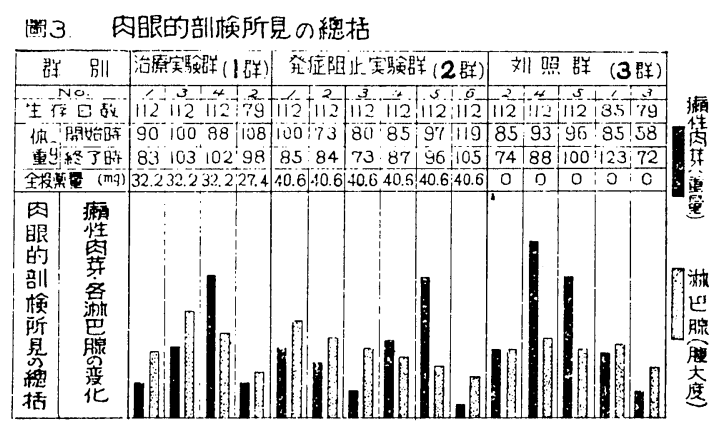

即ち政性肉声:の発現程度は 2 群 $<1$ 群 $<3$ 群の順であ り，淋巴腺腫脤の程度は之之巽り 2 群 $<3$ 群 $<1$ 群の順 を示した。

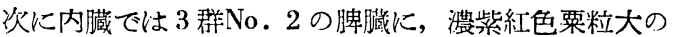
隆起物が辺在性に数二認められた以外には各群之も肉眼 的に顕著な異常所見はなかつた。

3）細菌学的所見：まず顆性肉记，各淋巴腺及び内欵 に打ける鼠霜菌の播布程度についての所見をヒストグラ ムに総括すると㹣4のようになつた。

即ちこれによつで明らかな如く, 鼠瀨菌の体内播布度 は肉眼的に所見の最も強かつた対照群に於て最大であ り，治療実験（第 1 ）群が之に次ぎ，発症阻止実験（第 


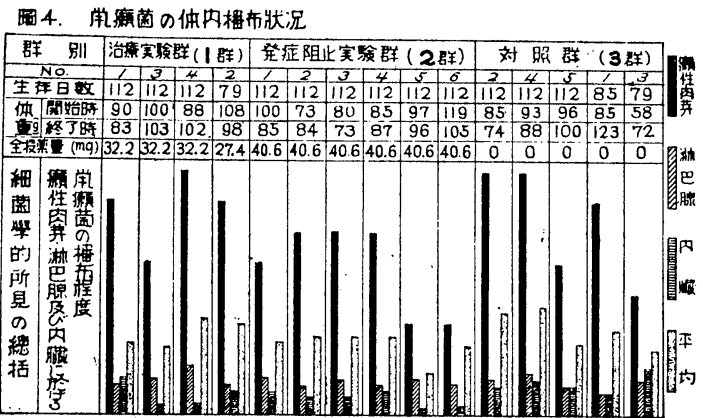

\section{2）群に於て最も小さかつた。}

な打一般に各試獣（ハムスター）よりの叙抹標本に於 ける鼠桷菌は INAH 投与に関係なく顆粒の鮮明なるの が多くて実験鼠瀨白鼠のそれに比してやや太く感じら れ，被染性にも異状はみられなかつた。

4) 病理組織学的所見: 演性肉茅, 淋巴腺, 肺, 肝, 脾及び胃よりの組織標本内の鼠瀨菌の分布は, それらに 於ける組織学的病変度と略一致しているように見受けら れた。一般にいつて組織学的病変は 3 群間に特にいら程 の質的の差異は示さなかつたが，然し INAH 投与群の 試獣では刘照群に比して病変部内にセンイ母細胞の浸潤 がより顕著のようでめり結合織か壞死巣に代つて次第に 增殖する傾向がより强いように思われた。辺在性粟粒大 隆起物を認めた対照群 No.2 の脾の病変は他群のそれに 比し特に選ぶ所がなかつた。

\section{総括並びに考按}

鼠制性肉芽の大きさ, 及び鼠瀨菌の体内分布度の所見 を以て鼠濑䍜患度の判定規準としらるとすれば今回の私 の実験成績よりすると INAH 投与は鼠瀨に対して発症 阻止効果並びに治療効果の両つながらを多少にかかわら ず発揮し得たすのと考えられるが，乙れら両効果を比較 すれば，その程度は発症阻止能の方が治療能に比してよ り大きかつたものと云つてよかろう。INAHは安田ら行 よると比較的短時間で結核菌に対しては殺菌的に作用す

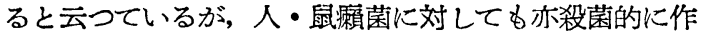
用しらるすのであるかどらかに関しては㚲く措くとして 野島等 ${ }^{10}$ は人瀨に対してはプロミンよりる効果は緩慢で はあるが相当の治効は認如れたと云つて抢り, 又鼠瀨 に対してる西村等 ${ }^{11)}$ によると鼠瀨白鼠15匹中 9 匹までに 於てその潰場が治熟し，更に 9 匹中 5 匹にに於て瀨腫が殆 ど触れなくなつたと報じている。他方実験モルモット結 核に対しては INAH が Streptomycin を凌ぐ治効を示し

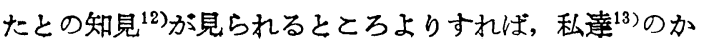

つての Streptomycin, PAS, 'libione, Promin \びCiepharanthin を用いての治鼠瀨効果についての実験成績では Streptomycin の治効が最大であると云う知見を一応得て はいるものの, 之よりも今回の私の INAH による鼠瀨 に対する阻止又は治療効果の方がより大きいのではない かとる思われるが再者同時实験ではないために刘比でき ないととは遺憾でむる。

それはそれとしてて Colesto'14) は Streptmycin と INAH との間には協力作用がない（但し非指抗性）から臨牀的 に両鼡併用の効果は期待できないからむしろ同時投与は 避けるべきであると警告しているととから見れば，対鼠 瀨の場合にも或はとのようなととがあるかも知れない。 今後検討されるべき点ではないかと考えられる。

次に INAH の毒性について Bernard Rubin等 ${ }^{15}$ はラ ツテの実験的亜急性或は慢性経口最大容量は $40 \mathrm{mg} / \mathrm{kg}$ と 云つているが，今回私の実験に供試したハムスターに対 しては，INAH投与を最初のらちは㤝ぼ $2 \mathrm{mg} / \mathrm{kg}$ の制合で 開始し次いで $3 \mathrm{mg} / \mathrm{kg} 2$ 週間, その後は $4 \mathrm{mg} / \mathrm{kg}$ の割合 になるように增量投与したとてろ，試畄の体重はむしる 漸増の傾向を示した。但し鼠瀨菌接種後 8 〜 10 週を境と して以後遂に漸減するに至つたので,之は或は INAH 連 用副作用の為かとも一応疑つても見たが INAH 非投与 の対照（第 3 ）群に於ても全く同様な体重漸減が見られ たので，乙の解釈の不当であることが判明しだ。

次に剖検上の所見についてみるに，右側膝べキ淋巴腺 は左側のそれに比し $2 \cdot 3$ の例外を除き同程度か或はより 以上に腫大して打り，且つ淡黑褐色斑が比較的多く表在 性淋巴腺に散見されたが，乙のような所見は前瓡 ${ }^{16}$ に於 てハムネター鼠瀨の所見として既に報告したところと符 合するところでめつだ。な招淋巴腺腫大度は 1 群 $>3$ 群 $>2$ 群の順を示し，之によると INAH による治潦実験 群に於て最も所見不良と云うことになつたが之等淋巴腺 の腫大は鼠瀨感染以外の要因によつても港起せられらる ところのものでめるから如上の順位で以て LINAH の効 果を云々するととは当を得ないものと思われるとと既に 私達の ${ }^{13)}$ 述べたところである。

次に INAH 投与群に於ける体内鼠瀨菌の形態並びに 被染性についてであるが，乙れは無処置対照群に於ける それらと比較して何ら特にいら程の異つたととろもなか つた。

最後に鼠攋菌の体內播布状態であるが，之は発症阻止 実験群の 1 部を除いては鼠瀨菌の体内分布度と瀨腫の大 きさとの間には必ずしも平行関係は見られなかつた。 
結論

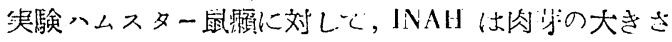
队び鼠瀨菌体內分布度の 2 点を鼠瀨䍜患度の判定規淮と して判断する場合には明らかに発症阻止前びに治療上多 少にかかからず見るべき効果がせる。

擱筆するに当り御愁切な御指導と御校閲をいたただいた 恩師占部教授に感謝の意を表します。

\section{主要文献}

1）光田・他14名 ：第26回日本䙾学会演説抄録，昭28

2) 林・他 7 名 :

3) 上川・馬島：

4) 大西・他 6 名 :

5) 谷村他・ 2 名 :

6) 重松・藤原

$\begin{array}{ll}\text { " } & \text { " } \\ \text { " } & \text { " } \\ \text { " } & \text { " }\end{array}$

7）市原・藤田

8）谷村・他 3 名：

9) 安田・他5名：·神戸医科大学紀要, 4(1),70, 昭 28

10）野島・他 2 名 ：第 1 回日本瀨学会西部地方会演説 抄塗 昭 27

11) 西村・河野：最新医学， 7 (11)，98, 昭 27

12）柳沢・他 3 名： 結核研究の進歩，1，42，昭28 （結核文献の抄踏速報 4 (4), 21, 昭28上り引用)

13) 高山・安元： レプラ, 22(1), 18, 昭 28

14.) P. J. Colestos: Rev. de la Tuberc. 16(7.8), 6701952 （結核交献の抄録速報, $3(12) 50$, 昭27より引用）

15) Bernard Rubin, G. Lee Hassert, Jr., Bernard G. H. Thomas, and John C. Burke: Am. Rev. Tbc., 65(4), 392, 1952

16) 高山：「レプラ」, 22巻へ近く揭載予定

\section{EFFECT OF ANTIBIOTICS ON MURINE LEPROSY}

\section{SHINJI NISHIMURA and MICHIYUKI KONO}

(Leprosy Section, Research Inststute for Microbial Diseases, Osaka University.)

\section{TARO MASUDA}

(Department of Dermatology, Osaka University, Medical School.)

Experimental studies were carried out on the inhibitory action of antibiotics on development of murine leprosy. Those antibiotics, Acidomycin (AM) (Thiazolidone Antibiotics of McLamor et al.), Streptomycin (SM) and Aureomycin (AUM) were studied and the results are presented below.

1. Acidomycin does not have an inhibitory action on the development of murine leprosy. (Fig. 1, 3 and 4)

2. Streptomycin has a moderate inhibitory effect on the development of murine leprosy. (Fig. 2, 3 and 4) (Fig. 5)

3. Aureomycin possesses no inhibitory action on the development of murine leprosy.

From these results and the results of previous studies chemotherapeutic agents, it is believed that antibiotics which are ineffective in experimental tuberculosis are also ineffective in preventing development of murine leprosy.

\section{癩の化学療法に関する研究（第13報）}

\section{— 鼠癩に対する抗生物質の影響 —}

\section{大阪大学微结物病研究所癩研究部（主任 谷村教授）}

胕村真二河野通之 